\title{
К 80-летию профессора Бориса Алексеевича Спасского
}

\section{В.И. Костицын}

Пермский государственный национальный исследовательский университет 614990, Пермь, ул. Букирева, 15. E-mail kostitsyn@psu.ru

(Статья поступила в редакииюю 25 августа 2017 г.)

Приведены краткие сведения о производственной, учебной, научной и организационной деятельности доктора геолого-минералогических наук, заслуженного работника высшей школы Российской Федерации, профессора кафедры геофизики ПГНИУ Бориса Алексеевича Спасского

Ключевые слова: Пермский госуниверситет, профессор Спасский. DOI: 10.17072/psu.geol.16.3.302

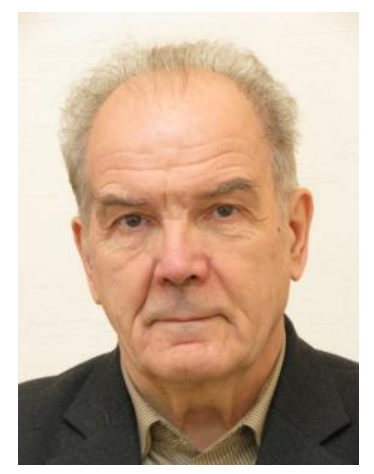

Б.А. Спасский родился 10 августа 1937 г. в г. Горьком (Нижний Новгород). В 1955 г. поступил на геологический факультет Пермского госуниверситета на отделение «Геология нефти». В 1961 г. окончил обучение по специальности «Геофизические методы поисков и разведки месторождений полезных ископаемых». После окончания университета работал в конторе (тресте) «Пермнефтегеофизика» оператором в полевых сейсморазведочных партиях.

Поступил в аспирантуру кафедры геофизики ПГУ 1 декабря 1963 г. С этого времени работает в Пермском университете на разных должностях: мл. научный сотрудник, ассистент, доцент, профессор кафедры геофизики (с 1994). В 1968 г. защитил диссертацию по теме «Исследование динамических характеристик отраженных волн в условиях Пермской области» на соискание ученой степени кандидата геолого-минералогических наук, научный руководитель - профессор А.К. Урупов.

В 1971-1973 гг. преподавал на французском языке геофизические методы на кафедре геофизики в Национальном институте нефти в Алжирской НДР (г. Бумердес). Принимал участие с докладами в научных геофизических конференциях с участием французских и американских специалистов. По возвращении в СССР некоторое время являлся переводчиком научных статей по сейсморазведке в Центральной геофизической экспедиции.

С 1974 по 1977 г. был заместителем декана по учебной работе геологического факультета ПГУ. В 1992 г. защитил докторскую диссертацию по теме «Изучение и учет верхней части разреза в сейсморазведке» (г. Екатеринбург, Уральский горный институт).

Основное научное направление изучение скоростных моделей верхней части разрезов для нужд нефтяной сейсморазведки и решения инженерногеологических задач. Данные исследования найдут применение на практике при создании комплекса программ, позволяющих упростить весь цикл процесса анализа сейсмических данных. В настоящее время им опубликовано более 200 работ.

Принимал активное участие в научно-исследовательских работах по договорам с предприятиями «Пермнефтегеофизика», «НОВИК», «ЛУКОЙЛ - Пермь». В качестве эксперта Государственной комиссии участвовал в определении запасов нефти по ряду месторождений. Всегда за- 
нимался общественной работой, был членом парткома университета в течение 10 лет, многие годы являлся председателем методической комиссии геологического факультета и методического совета Пермского университета. Принимал активное участие в спортивных мероприятиях.

Ему присвоено звание: «Заслуженный работник высшей школы Российской Федерации», награждён медалями «Ветеран труда», имени В.В. Федынского «За выдающийся вклад в геофизику» и имени А.К. Маловичко «За достижения в геофизике», Почетной грамотой Правительства Пермского края. Включен в энциклопедический сборник «Геофизики России» (2001, 2005).

\section{Библиографический список}

Спасский Б.А. Учет верхней части разреза в сейсморазведке. Иркутск: Изд-во Иркут. ун-та, 1990. 184 с.
Спасский Б.А., Митюнина И.Ю. Использование первых волн в сейсморазведке методом отраженных волн для изучения верхней части разреза. М.: Геоинформмарк, 1992. $46 \mathrm{c}$.

Спасский Б.А. Основы цифровой обработки данных сейсморазведки: учебное пособие. Пермь: Перм. ун-т, 1986.96 с.

Спасский Б.А., Герасимова И.Ю. Сейсмостратиграфия: учебно-методическое пособие / Перм. ун-т Пермь, 2007. 267 с.

Спасский Б.А., Герасимова И.Ю. Теоретические основы обработки геофизических данных: учебное пособие. Перм. ун-т, Пермь, 2011. 190 c.

Sppssky B. Theorie de lelasticite. Boumerdes, Alger,Institut National des Hydrocarbuves, 1972. 39 p.

Emchanov L., Korchikov Y., Spassky B. Prospection sismique. Appareillage, equipement. INH. Boumerdes, Alger, 1974. 187 p.

\section{To 80 ${ }^{\text {th }}$ Anniversary of Professor Boris Spasskiy}

\section{V.I. Kostitsyn}

Perm State University, 15 Bukireva Str., Perm 614990, Russia

E-mail: kostitsyn@psu.ru

Brief information on the working, educational, scientific and organizational activities of Doctor of Science in Geology and Mineralogy, Honored Worker of the Higher Education of Russian Federation, professor of Geophysics Department of the Perm State University, Boris Alekseevich Spasskiy is given.

\section{References}

Spasskiy B.A. 1990. Uchet verkhney chasti razre$\mathrm{za} \mathrm{v}$ seismorazvedke [Correction for upper part of section in seismic surveys]. Irkutsk, Irkutsk University Publishing House, p. 184. (in Russian)

Spasskiy B.A., Mityunina, I.U. 1992. Ispolzovanie pervykh voln $\mathrm{v}$ seismorazvedke metodom otrazhonnykh voln dlia izucheniya verkhney chasti razreza [Usage of first arrivals in seismic reflection for study of the upper part of the section]. Moskva, Geoinformmark, p. 46. (in Russian)

Spasskiy B.A. 1986. [Osnovy tsifrovoy obrabotki dannykh seismorazvedki [Basics of digital processing of seismic data]. Perm, Perm State University, p. 96. (in Russian)
Spasskiy B.A., Gerasimova I.U. 2007. Seismostratigrafiya [Seismic stratigraphy]. Perm, Perm State University, p. 267. (in Russian)

Spasskiy B.A., Gerasimova I.U. 2011. Teoreticheskie osnovy obrabotki geofizicheskikh dannykh [Basic theory of geophysical data processing]. Perm, Perm State University, p. 190. (in Russian)

Spasskiy B. 1972. Theorie de l'elasticite. Boumerdes, Alger, Institut National des Hydrocarbuves, p. 39.

Emchanov L., Korchikov, Y., Spasskiy, B. 1974. Prospection sismique. Appareillage, equipement. INH. Boumerdes, Alger, p. 187. 